In other cases, when general pathological causes can be ruled out, orthoptic training with base-in prisms may be tried, with the hope of increasing the abduction reserve.

The wearing of permanent weak base-in prisms (which must not cause diplopia) can be prescribed at the same time.

As a temporary measure, in older patients, who have to do much close work relieving prisms (base-out) must be ordered.

\title{
THE THIRD BRAZILIAN CONGRESS IN OPHTHALMOLOGY. JULY, 1939
}

BY

\section{E. E. CASS \\ LONDON}

ON Wednesday, July 5th, in company with Professor Linneu Silva, Professor Moacyr Alvaro, Professor Correo Meyer and Dr. Assis Brasil, I flew from Rio de Janeiro to Bello Horizonte, the capital of Estado do Minas Gerais, where the Third Congress of Ophthalmology was being held. We had to fly high, as the country is very mountainous and our descent was too sudden to be pleasant. We were met by Professor Santa Cecilia, the President of the Society and by Dr. Hilton Rocha, the Secretary. We were awaited with some curiosity, as Professor Silva had sent a telegram

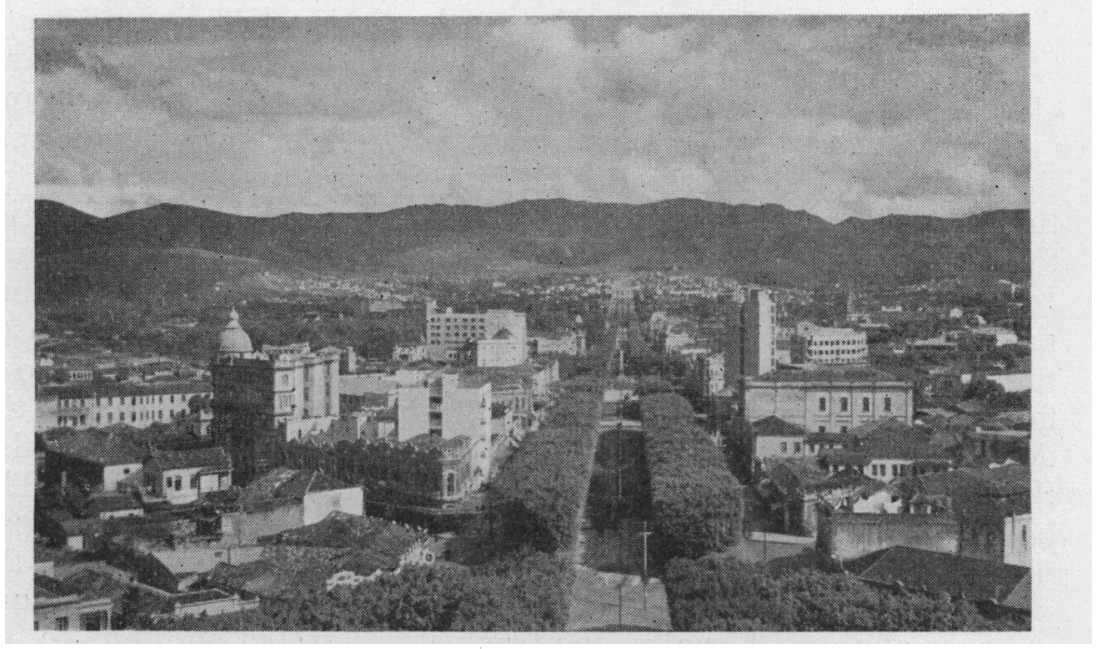

Av. Aff. Penna-Bello Horizonte. 
in Rio, in which he had written: "Arriving by plane, Moacyr, Miss Cass and self," but unfortunately, the English name was too much for the Brazilian clerk and the telegram read : "Arriving by plane, Moacyr, Moses and self."

Although winter, the sun was warm and the air clear and exhilarating. Bello Horizonte is a beautiful little town with broad streets and flower-beds and is situated on high ground and was planned and built in 1886 as the capital of the state. Alvaro remarked that if my English friends knew I was 300 miles north of Rio, they would think that I was living amongst Indians. The little hotel was clean and comfortable and its excellent laundry and pressing service would set a good example to many of our hotels.

As the Congress officially opened later in the day, Moacyr took me to the very modern museum, where one saw the beautiful stones of Brazil, precious and semi-precious in large quantities. Brazil is also rich in the most beautiful woods and the residential quarters of the cities have most attractive houses, the Brazilians seeming to have a great ability for building attractive and original residences. The museum also showed us the flora and fauna and industrial products of various parts of Brazil. Twenty years ago, they manufactured very little and quite a lot of their boots and clothes were obtained from England, and they are very proud of their progress in manufacturing their own materials. The custodian thought we were both English and said in Portuguese to his friend: "They have come to steal our wealth."

My first lunch at Bello Horizonte was astounding on account of its size. It's cooking was excellent. Unfortunately, I thought the first course of assorted cold meats was the main one and ate heartily of it, only to discover to my dismay that it was followed by soup, fish and a Brazilian entree made of spaghetti and spiced meat and after this, two meat courses and then jellies made of bananas and quinces which are eaten together with milk cheese. It was here that I first met Professor Penido Burnier and his family, and for this man I have an intense admiration. He lives in the provincial town of Campinas, where, twenty years ago, he started his own Institute of Ophthalmology in a small house with beds for twenty patients. I was lucky enough to be invited to lecture at his Institute, which has now grown from that one small house into a flourishing clinic. Ophthalmology, as practised in Brazil and the Argentine, is very different from our arrangements here, and I think we may learn something from them in this respect. The hospitals are simply for the poorest of the poor who can pay nothing, and ophthalmologists run their own clinics and the patient who has anything wrong with his eyes goes straight to one of these clinics. Usually, the fees vary from ten shillings to $\notin 1$ and therefore almost anyone can get the best advice for a moderate 
fee. This relieves the hospital clinics and caters for the large body of people, who, in this country, have to come to our hospital clinics as they cannot afford a specialist's fee, but incidentally can afford to pay something and would rather do so if it could be arranged. At the Institute of Penido Burnier, there are now eight ophthalmologists working and five ear, nose and throat surgeons. Each ophthalmologist has his own consulting-room, and everywhere there are modern instruments. Besides these clinics, there are modern and well equipped X-ray departments and laboratories. There is a room for lectures, meetings, etc., provided with an epidiascope and film projector. The Ear, Throat and Nose Clinic is the most modern and has beautiful furniture and a comfortable waiting-room with flowers and magazines. There are three classes of in-patients : in the most expensive, each patient has his private bedroom, sitting-room and his own bathroom; in the second class, there are private bedrooms but no sitting-rooms and they share bathrooms : the third class is for the very poor, and it consists of little wooden bungalows. On the veranda of one of these, I saw an old negress who had been a slave in the 'eighties waiting for an operation for cataract. In the clinic itself, I was lucky enough to see two cases of cysticercus causing detachment of the retina. One cannot help admiring the man who had the ability to found such a clinic and make a success of it, especially when one considers the difficulties of transport in an enormous country like Brazil.

My first day at the Congress was handicapped by the fact that I spoke Spanish and not Portuguese. Although there is a great similarity of the language, the accent of the Portuguese as spoken in Brazil is very difficult to follow.

The Inaugural Session of the Congress was held that evening in the Automobile Club. About eighty ophthalmologists were present, also some of their families attended. Moacyr had previously told me that they realised that some bad papers were produced, but he said that it was necessary to encourage people to come. Brazil is an enormous country and many had travelled from two to five days to get to the Congress and I met one man who had travelled as many as eight days. Moacyr said that if a man felt he could read a paper it would encourage him to come, and if he came, he would have an opportunity of learning something. If he was any good, he would realise later that his paper was a bad paper, but would be encouraged to work and produce something better. It is very essential that the Brazilian ophthalmologists should come to their congress for some of them are shut away miles from any centre of ophthalmology and it gives others a chance to discuss ophthalmology with other ophthalmologists and to learn new methods.

Thursday, July 6.-On Thursday morning, I left Moacyr busily 
typing his paper. He is one of the most energetic people that I know. He works until nine o'clock at night even on Saturday and produces papers and translations etc., as well. He speaks English like an Englishman and German like a German, also French and Spanish. He is always late because he has too much to do. I once asked him to dinner in London and two hours after he was invited, he walked in quite calmly, although the cook was almost having hysterics.

An ophthalmologist of Syrian extraction took me to swim at the Tennis Club. It was a very beautiful, large, modern, clean bath, but to our amazement we found that no-one was allowed to swim without a medical certificate. When we did find this out, Dr. Ferriche had already donned his trunks! We were accordingly accompanied by the Secretary to the Doctor, who lived about five minutes away, Dr. Ferriche being attired in dressing-gown and no shoes! The Doctor obligingly gave us certificates without examining us and also delayed us by showing us his statistics. No people with tuberculosis, uncompensated heart disease, skin disease, obvious manifestations of venereal disease, etc., were allowed in the bath. He had statistics on how graded swimming exercises improved the health in various diseases. There was also a small bath for children and he had statistics on the improvement in health of all the school-children of Belo Horizonte due to exercises, etc. He was a most hard-working, industrious young man and would have talked all the morning if we had let him. By the time we got to the bath, the sun had nearly disappeared and that water was the coldest thing I had met for a long time.

At two o'clock, the real work of the Congress began, the first paper being an excellent work by Correo Meyer on the "Ocular manifestations of disturbances of metabolism." He spoke a good deal on the metabolism of lipoids and included in his work observations on cases of Tay-Sachs, choroiditis, Niemann-Pick, SpielMeyer degeneration, etc.

Penido Burnier then gave a well-illustrated and interesting paper upon " ocular cysticercus." He said that since 1924, 102 cases of ocular cysticercus had been found in Brazil, 74 of these being in his own clinic and in one of these cases both eyes were affected. Cysticercus could appear in the conjunctiva, the vitreous, the anterior chamber and in front of, or behind the retina. It was always as well to suspect this disease in detachment of obscure origin. In cases of cysticercus of the conjunctiva, the scolex could be seen in the cyst. Cases affecting the retina showed detachments and cataract complicata-and it was sometimes difficult to diagnose from a retinal cyst. The complement fixation test was a positive proof, but on the whole, when the disease affected the interior of the eye, it was noi easy to diagnose. He had seen it in one eye that 
had been removed because a diagnosis of sarcoma had been made. Dr. Silva then quoted another case in which a cataract had been removed and then a cysticercus was found in the vitreous. Dr. Belfort Mattos of Sao Paulo showed some retinal photographs. Dr. Conti gave a short paper on his experiments upon retinal circulation and the session ended.

All through the sessions of the Congress they used to produce small cups of strong black coffee and, believe me, it was necessary when some sessions of the last days went on into the small hours of the morning. Brazilians are without the inhibitions of the English and all meetings lasted for a long time as most papers were freely discussed.

Malbran, who is a charming and hard-working Argentine ophthalmologist, arrived that evening. He and Adrogue have written an excellent book on " Squint."

Friday, July 7.- The whole of Friday's sessions was given up to the consideration of the problems of trachoma. Work started at 8 a.m. Dr. Lech, who works in Penido Burnier's clinic, spoke of his experiences of the treatment of trachoma with sulphanilamide. He had a group of cases treated with and without this drug and his conclusions were that on the whole this drug was of some use in the treatment of this disease. A lively discussion followed, where the general consensus of opinion seemed to be that up till now its utility had not been established. Various other papers were then read upon trachoma in Brazil and its treatment.

In the afternoon, the whole Congress departed in cars to visit the iron mine "Siderurgica Belgo-Minera." It was a most exciting ride. We wound round and round the mountainside on earth roads which periodically get washed away and are full of stones and potholes and our Jehu had ideas about driving. At first, it was a terrifying experience and after a nasty skid at one corner, Moacyr expostulated on his speed. The drivers on our expeditions were usually negroes and mulattoes and always joined in our conversations. I liked the negroes of Brazil; they are quite different in character from the North-American negroes and there is not the same colour bar in this country and the negro has none of the inferiority complex of the negro of North-America; they are, in consequence, very pleasant people.

The hills were dark green in colour, so unlike our English green, with reddish patches of earth and rock and few trees and the dust was appalling.

First, we visited the charming old Indian village of Sabara. Here was the typical Brazilian plaster and wood church, very ornate and grand inside, with brightly coloured images in rather tawdry vestments. Opposite was the cemetery with the coffins in the wall. Here I took a photo and funnily enough, when I printed it, the tomb I had focused was that of a doctor. 
At the iron mine, we got covered with still more red dust and after having seen the furnaces and how the molten iron ran into troughs and how the red-hot iron blocks were flattened into long thin bars, we retired and had tea, consisting of beer or lemonade and sandwiches at the club belonging to the mine.

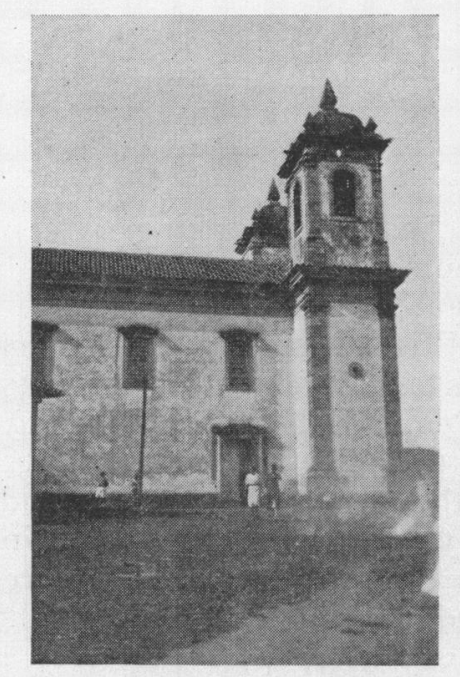

Norsa Senhora do Carmo-Sabará.

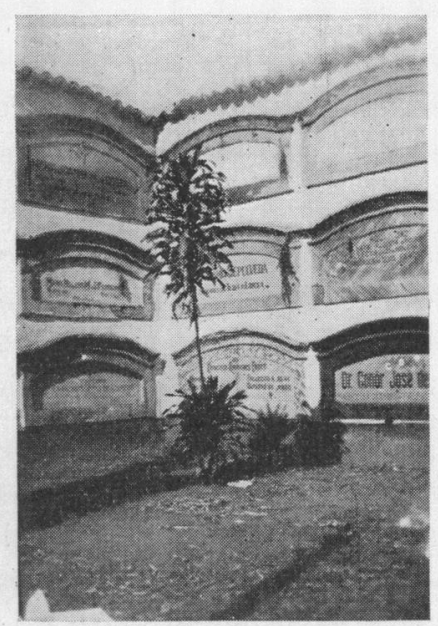

Cemiterio, im Sabará.

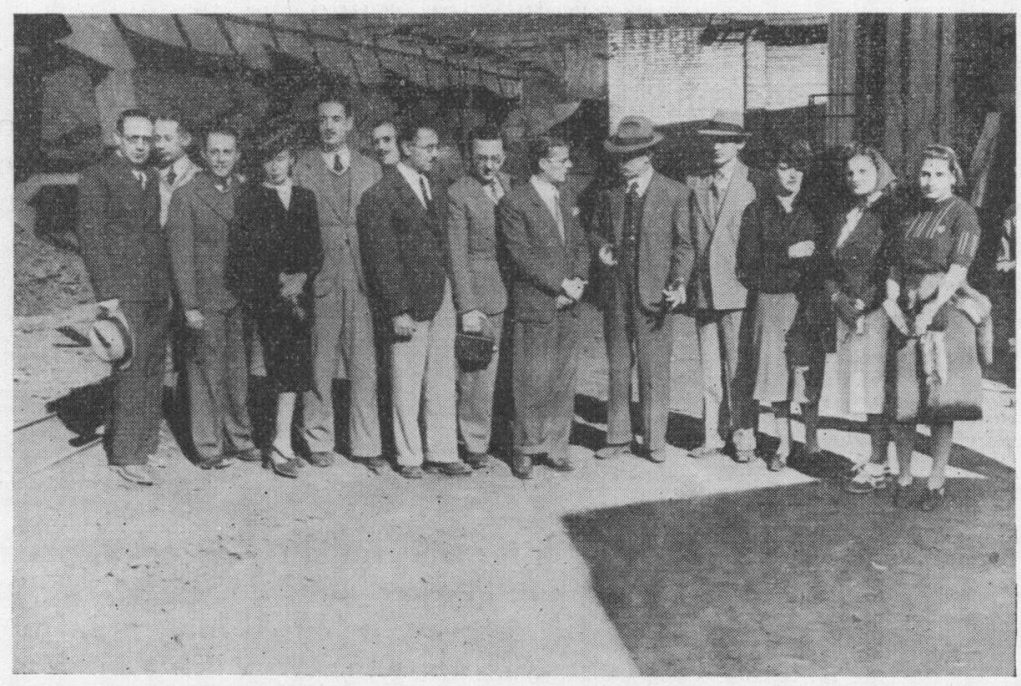

Group of Congress at the iron mine. 
After dinner, I was too weary to attend the evening session, as the strain of following the Portuguese and the change of altitude after staying at Rio was too much for me. In fact, the Brazilians wore me out as they started their days at $8 \mathrm{a} . \mathrm{m}$. and ended in the small hours.

Saturday, July 8-The next morning, I overslept and found that the Congress had departed to two different hospitals to see operations. I chartered a taxi and requested to go to one hospital. On arrival, the porter seemed rather surprised at my request to be taken to the operating theatre and was even more puzzled when I said that all the Congress was there. Finally, I was shewn into a waiting-room and when a lady in an advanced stage of pregnancy was shewn in, my suspicions that I had come to the wrong part of the building were confirmed! Finally, I was rescued by a kind gynaecologist and driven round in his car to the ophthalmological block.

I saw a modified Toti's operation very nicely and neatly performed, the operator using his own particular forceps, which were also a needle holder and seemed very handy for sewing the mucous membrane of the sac to the mucous membrane of the nose. After this I was requested to examine a doctor's child with a squint, which was the result of a birth injury, due to contracted pelvis and forceps delivery, and combined with muscular paralyses, the right eye was blind. I was very sorry for the mother and father as the mother had nearly died on delivery and was told not to risk another child.

At 2 p.m., Malbran read an excellent paper on the pathology of strabismus. He stressed the fact that the cause of squint is not one, but many. He discussed the general factors and the ocular factors and showed how it is impossible to group all squints under a common denominator. He realised also how difficult it was to get a perfect classification for all cases of strabismus. Among his final conclusions, he said that anatomical factors must first lead to anomalous positions of the eyes, combined or not with factors of innervation and that he could not agree that weak fusion was a principal cause in determining a squint. This paper, read in Spanish, was much appreciated and applauded. After this, the Doctors Campos of Rio read a paper on submucous resection of pterygium. Dr. Robin of Rio read a paper on cyclodialysis in choroido-retinitis and uveitis with hypertension and Dr. Borges Dias of Rio a paper upon heterophoria due to visual fatigue.

After this session, I had my first meeting with Arruga, who had come to Brazil to operate upon President Vargas's father. We were entertained at a cocktail party at the museum and had a quiet evening afterwards as there were no further lectures that evening. He was extraordinarily kind to me, as he read and corrected all 
my six lectures on squint, written in my bad Spanish and it was Arruga who made the epidiascope work for me and projected my film for me in Rio. He is simple, unassuming and friendly with all and is much beloved by the Brazilians.

Sunday, July 9.-Sunday was given up to social amenities. In the morning, we went to the tennis club where people amused themselves in divers ways, most of them sitting on the roof drinking cocktails and watching the swimming and sports. We had most hilarious lunch, we being Moacyr, Malbran, Arruga and an Ear, Throat and Nose specialist named Leité. Arruga is no mean raconteur and he gave us amusing tales of Gonin's absentmindedness. Apparently, Gonin never could keep an umbrella and so finally his wife would only buy him cheap ones; this annoyed Gonin so much that he went and bought himself a beautiful expensive umbrella! He arrived home triumphant and said to his wife : "Look at my beautiful new umbrella!" "Where?" she demanded. Gonin looked down; in his hand was an old decrepit monstrosity of an umbrella. On his way home, he had been to see a patient and had left his beautiful umbrella at the patient's house! We laughed so much that various other oculists joined us and finally Arruga broke up the party with a very witty but rather broad story and then said: "This is dreadful; when Miss Cass returns to England and they ask her what kind of a man is Arruga, she will say he is a man who tells dreadful stories!"'

That afternoon, we were all commanded to the Governor's palace. He lives in a beautiful house, facing a long row of tall trees. From his windows are views of the hills and his own garden and flowers. We all shook hands with him, various speeches were made and then we shook hands again and departed.

A garden party at the waterworks, given by the Minister of Health, was the next item on our programme and all Bello Horizonte turned out in its best to greet us. We had tea on a terrace and, as the sun fell the orchestra started to play and dancing began. Brazilian dancing is very energetic and consists chiefly of " Machichis" and " Sambras," which are negro in origin.

I was too weary after this to visit a native fair, where Alvaro told me that unfortunately I had missed some excellent negro dances.

Monday, July 10.-Our last days at Bello Horizonte were interesting but crowded and we were all tired. Monday we left the hotel at seven a.m. to visit the gold mine of Morro Velho. Once more we had this perilous journey over the mountain road, branching off on another track before reaching Sabará. This gold mine is owned by an English company and there is a colony of 300 English people, consisting of the officials of the mine and their families. Funnily enough, when I reached home one of my first patients was an English girl, born in Morro Velho, whose family 
still live there. The entrance to the grounds of the company are beautiful with palm trees, tropical shrubs and cultivated gardens. We were met at the guest house by an Englishman, who looked as though he wondered what in the world an English woman was doing mixed in with a crowd of Brazilians!. It was really rather amusing and Moacyr and I had a quiet laugh over it. We were not allowed down the mine, as there were nearly a hundred of us and anyway, the miners consider it bad luck for women or priests to descend the mine. The ore in this mine is treated to a series of crushings and washings to remove the gold and also to treatment by chemicals to remove impurities. Finally, we arrived at the melting house and saw a solid bar of gold weighing $60 \mathrm{lbs}$. and

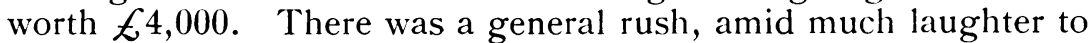
catch hold of all this wealth. During our wandering through the grounds of the mine, I snapped Arruga in company with our official photographer who went everywhere with us. This gentleman was so pleased at the honour of being photographed with Arruga that, on condition I gave him the negative, he developed all my films free of charge. In South America, the first people who greet you are the press photographers and press agents and much to my indignation they woke me at 8 o'clock my first morning at $\mathrm{Rio}$ and asked if they could come up to my room and photograph me. I declined vehemently, but they waited patiently for an hour until I arrived downstairs. Our official photographer was very nice, whilst the press agent at Diario was a simply beautiful curlyheaded Adonis, who said, "Oh, Miss Cass, you give me an interview and let us be photographed together."' Somehow I gave him the slip.

The Committee and President were chosen for each session of the Congress. That afternoon, as the subject was that of "squint," they paid me the honour of asking me to be on the committee. Professor Linneu Silva of $\mathrm{Rio}$ read an excellent paper on the medical treatment of squint, which he said was the foundation of the treatment. There were various and many factors in the aetiology as Malbran had already stressed and a squint must be regarded as a symptom. He said that orthoptic treatment was indispensable for restoration of function as a complement to the aesthetic treatment, which was that of operation. Moacyr Alvaro then followed with another extraordinarily thoughful and well written paper on the surgical treatment of squints. He gave an extensive historical survey of the subject accompanied by lantern slides and diagrams and showed from statistics taken from many authorities that tenotomy was a bad operation. These two papers and the discussions that followed took up most of the afternoon.

At 9 o'clock, the session started again. Professor Pimentel spoke upon Marcus Gunn's syndrome. He had observed that his 
" jaw-winking" is of common occurrence in cats when they are eating, the phenomenon occuring on the side of the face the cat is using for mastication. He illustrated this by an amusing film, in which he showed a patient with this conditon and then some cats eating. He suggested that Gunn's syndrome was really some atavistic phenomenon which some people showed also in being able to waggle their ears, etc. Two ophthalmologists then obliged, one by waggling his ears and the other his scalp, but the doctor who stole the show was a man who could do both at once! After much laughter, the business of the evening was resumed. Professor Pimentel kindly lent me his film to show at the Royal Society of Medicine, which I did in the Spring of last year.

Professor Leité then read a paper on tumours of the conjunctiva. Dr. Barros's paper on the appearance of leprosy in the anterior segment of the eye was read by Moacyr Alvaro. It was an excellent paper, beautifully illustrated by the author's own paintings. When I later went to Sao Paulo, Dr. Barros took me to the leper colony of Padré Bento where I saw case after case of nodules on the conjunctiva, corneal nerves with nodules of leprosy, cauliflower growths on the iris, small multiple nodules on the iris and keratitis, etc. He had made an exhaustive study of leprosy on the eye and had some wonderful material of what is rather a disheartening condition to deal with.

The following papers were also read :-

Dr. Santa Cecilia on "Persistent pupillary membrane adherent to the cornea." Geraldo Queiroga (Bello Horizonte) on " Consideration of the blue appearance of the fundus of the eye following the use of methylene blue."

Conde (Bello Horizonte) on "Atrophy of the papilla following the operation of Caldwell Luc."

Dr. Rocha and Paulo Elejada (Bello Horizonte).-_ "Concerning the classifications of glioma of the retina."

Dr. Machado on "Neuro-epithelioma of the retina."

The discussion continued until 2 a.m., but I am afraid that at midnight I faded out.

Tuesday, July 11. - We were invited by the Governor to view the model Agricultural College and Farm of Florestal. We proceeded by cars over the usual dusty, but this time not so perilous, road and after a journey of about $2 \frac{1}{2}$ hours, arrived at a most beautiful spot. Surrounded on one side by hills and shrubs and on the others by miles of undulating plains lay the College and farm buildings. We drove to the Manager's house which was squarely built and surrounded on three sides by a veranda. We had been invited to a " Churrasco." Behind the house, tables were laid and an orchestra was playing and at the far end of the tables the meat was cooking. "Churrasco" is the most delicious meat in the world. Whole sides of young pigs, lambs, etc., are soaked over-night in herbs and spices and then next day a trench 
is dug in which is placed a wood-fire. When there are nicely glowing embers, the meat, with spikes driven through it into the ground, is placed round the fire and cooked. The Governor also supplied marvellous wines and the waiters brought round the whole joint on its spike and carved off any piece for you that you fancied. After lunch, speeches were made, when, to my horror, they yelled my name and I was pulled to my feet by the doctors next to me. I then made my maiden speech in Spanish. All I could think of to say was how pleased I was to be in South America after wanting to come for such a long time, how beautiful their country was, and how, although I was a complete stranger and the life in their country was so different from my own, they had been so kind to me that I felt completely at home. I then sat down rather abruptly, but they seemed quite pleased and were very polite about it, as always, and all was well. After lunch, we visited the cows which were in the cleanest stalls I have ever seen. Someone heard I wanted to see the horses, so a groom was fetched and the Governor, a few others and myself went to the stables where a beautiful black horse was produced. The groom said I might ride it, but I was dressed in a cotton frock so I had to refuse with much regret on $m y$ part (I do not know about the horse!). The party ended at the guest house of the College, where we danced in the patio, more sambras and machichis, finally joining hands and dancing in a ring in and out of the patio. With much regret, we had to return to Bello Horizonte after a perfect day, so as to attend to the business of the Congress once more.

Once more at 8 p.m., we started with the following papers (and once more the session ended at 2 a.m.) :-

Correo Meyer (Porto Alegre).- " Contribution to angioid streaks of the retina."

Paul Pimental (Niteroi).- "Consanguinity and hereditary disease."

ALMEIDA and BURNIER JUNior (Campinas).- " Adiposis of the Cornea."

Paiva Concalres (Rio). - "Results obtained in some cases of atrophy of the optic nerve by combined medical and surgical treatment."

Geraldo QUEIROGA (Bello Horizonte).- "Considerations on the change in acidity of the vitreous in glaucoma."

Hilton Rocha (Bello Horizonte).-- " Geron-toxon duplex."

JONAS ARRUDA (Rio).- "Cutaneous and ocular avitaminosis A."

MOURA BRASIL (Rio).- " Surgical treatment of retinal detachment."

CYRo DE REZENDE (Sao Paulo).- "The cornea of the corpse as material for corneal grafting."

Wednesday, July 12.-Arruga operated at one hospital in the morning, but, unfortunately, I never saw him as I had to wait for Moacyr and had to see a child with a squint at another hospital. Luckily, I had Moacyr's little instrument for measuring the angle, but otherwise I had nothing. It was a child of eleven, who had not even worn its glasses and I was quite sure that it had a false correspondence. I had been left with two cheerful young assistants to supply all my needs, but, alas, there was only an antique stereoscope! However, I had a brain-wave; with the aid of a mirror 
from my bag, a torch and the perimeter and my knowledge of the angle, I solved my problem. It was a Heath Robinson apparatus, but it gave me ideas for further use. The child had a false correspondence! But I still regretted not seeing Arruga operate!

We then had a farewell lunch in the hotel, during which lunch, various people had to leave and catch trains and it was a hilarious affair.

At 2 p.m., the last session started. This session was followed by discussing arrangements for the 4th Congress and the meeting

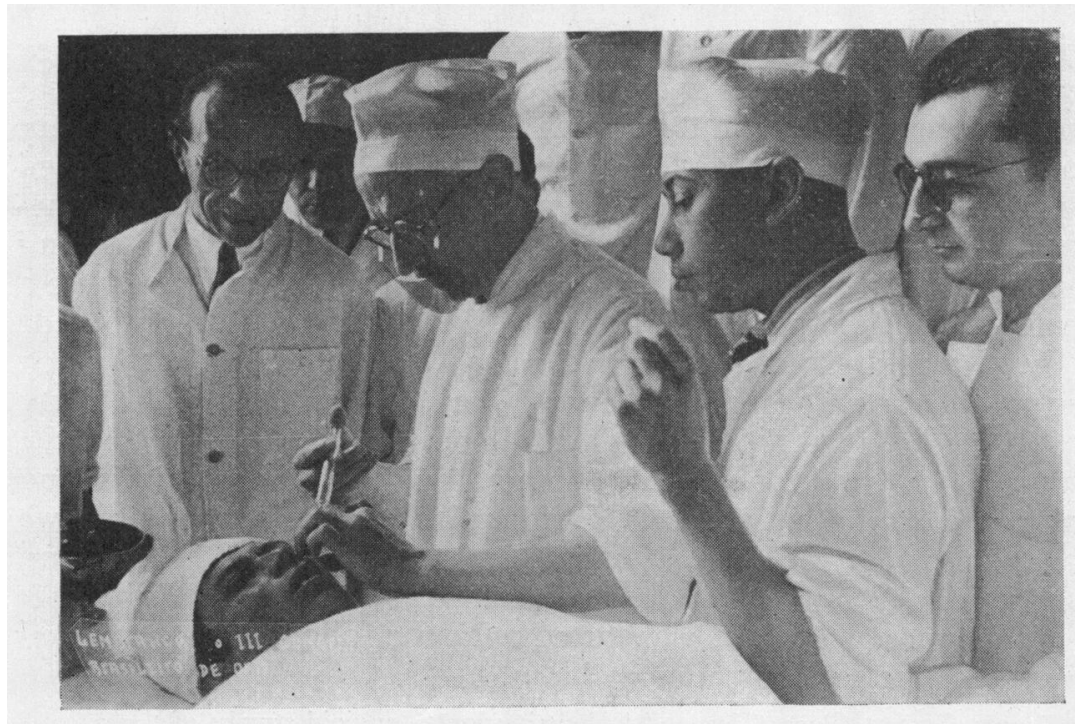

Arruga operating

broke up at 8 p.m., with the final closing session commencing at 9 p.m.

The papers read were :-

Dr. Almeida (Campinas) (Read by Penido Burnier).—“"Ten years of the surgery of cataract."

Dr. Semeraro (Barbacena).- “ Intra-capsular extraction.”

DR. TAVARES. - "The treatment of symblepharon by a contact glass."

Dr. Donate Valli (Varginha).- " "Our experience in 57 dacryo-cystotomies according to the technique of Dupuy-Dutemps."

Dr. Aureliano Fonseca (Sao Paulo).- " Associated movements of the maxilla and upper lid-(acquired form)."

Dr. Carlos Alberto Correa (Bello Horizonte)._-“ Traumatic ophthalmoplegia sensory-motor."

The closing session was attended by the Governor and after some speeches, the Congress terminated with a most enjoyable ball and again more energetic Brazilian dances.

There is one little thing I would like to point out; that is, the 
custom for speakers both in Brazil and the Argentine to read their papers sitting down and I think the idea is an excellent one. One can speak better when one is comfortable and it gives the nervous person confidence.

The following morning, we had rather a rush to get to the airport in Moura Brasil's car. There I took an amusing photo as a momento. Arruga, Moacyr and I then returned to Rio, all rather

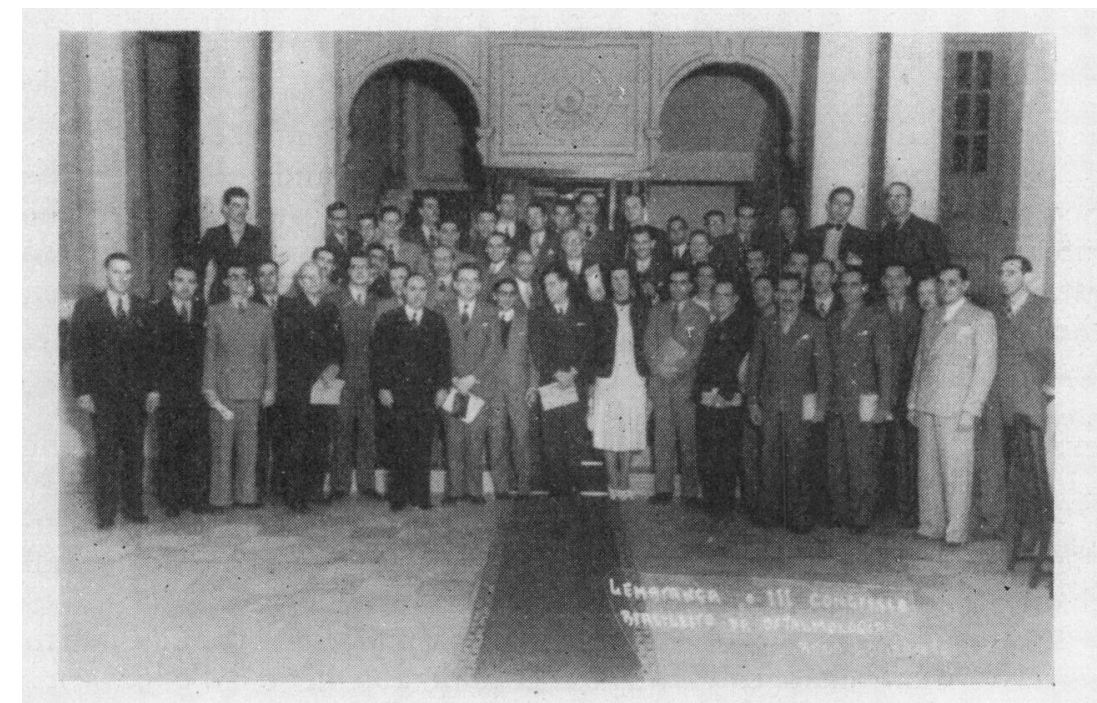

Group of some of the members of the Congress with Malbran at right centre, front row.

weary and Moacyr and I had lunch at Alba Mar, both horribly deaf and neither being able to hear a word the other said. After that, Moacyr returned to Sao Paulo and I had a few days' rest before starting my lectures in Rio.

I was exceedingly glad to have been able to go to this Congress in a country so far from my own, but was only sorry that my knowledge of Portuguese hindered my understanding and appreciating more of their scientific work. I can never forget their extreme kindness and hospitality to me and only hope that one day I may be able to repay it in a similar fashion. I would like to pay a tribute to the organising ability of the Committee at Bello Horizonte, whose management of a hundred or more people was so excellent and whose arrangements never suffered a hitch. I would also like to thank that magnetic personality, Moacyr Alvaro, for all his consideration and kindness to me, for his extreme efficiency in organising my visit to his country and for being the chief instigator of my " rolling down to Rio." 